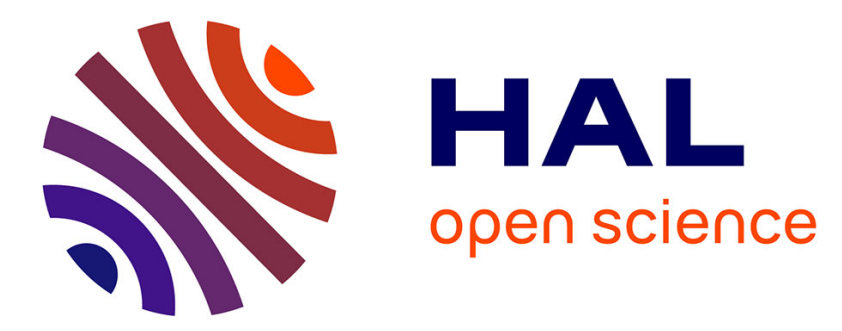

\title{
MULTIBEAM CO2 LASERS FOR INDUSTRIAL APPLICATION AND PERSPECTIVES OF THEIR DEVELOPMENT
}

\author{
F. Lebedev, A. Glova, O. Kachurin, A. Napartovich, V. Pis'Menny
}

\section{- To cite this version:}

F. Lebedev, A. Glova, O. Kachurin, A. Napartovich, V. Pis'Menny. MULTIBEAM CO2 LASERS FOR INDUSTRIAL APPLICATION AND PERSPECTIVES OF THEIR DEVELOPMENT. Journal de Physique IV Proceedings, 1991, 01 (C7), pp.C7-175-C7-178. 10.1051/jp4:1991746 jpa-00250988

\section{HAL Id: jpa-00250988 https://hal.science/jpa-00250988}

Submitted on 1 Jan 1991

HAL is a multi-disciplinary open access archive for the deposit and dissemination of scientific research documents, whether they are published or not. The documents may come from teaching and research institutions in France or abroad, or from public or private research centers.
L'archive ouverte pluridisciplinaire HAL, est destinée au dépôt et à la diffusion de documents scientifiques de niveau recherche, publiés ou non, émanant des établissements d'enseignement et de recherche français ou étrangers, des laboratoires publics ou privés. 


\title{
MULTIBEAM $\mathrm{CO}_{2}$ LASERS FOR INDUSTRIAL APPLICATION AND PERSPECTIVES OF THEIR DEVELOPMENT
}

\author{
F. LEBEDEV, A. GLOVA, O. KACHURIN, A. NAPARTOVICH and V. PIS'MENNY \\ Branch of I.V. Kurchatov Atomic Energy Institute, 142092 Troizk, USSR
}

ADstract-The modern state and perspectives of development of high power multibean $\mathrm{CO}_{2}$ lasers for surface treatment are described.

\section{Introduction.}

The broad applioation of lasers for thermal technology stimulates a search of new, more effective and high power laser systems. In this paper we would like to discuss moderm state and perspeotives one of new direction, connected with development of high power diffusionally cooled $\mathrm{CO}_{2}$ lasers of next generation-multibeam $\mathrm{CO}_{2}$ lasers (MBI).

The advantages and demerits of traditional high power diffusionally cooled CO lasers are well known. In spite of their simplicity and fast gas flow ${ }^{2}$ absence these lasers have large dimensions, many optical elements. Their power is limited on the level $1-2 \mathrm{~kW}$ because of limitation of total length of active medium. Besides, their efficienoy is quite low and as a rule they need high voltage power supplies. Ihese demerits decrease the competitiveness of such lasers with fast flow $\mathrm{CO}_{2}$ ones, when laser power exceeds $1 \mathrm{~kW}$.

In result of our aotivity we would like to increase output power of diffusionally cooled $\mathrm{CO}_{2}$ lasers very essentially (up to $50 \div 100 \mathrm{~kW}$ ), to increase its efficiency up to $10 \div 15 \%$, to minimize the number of optical elements, to decrease voltage power supply and of cause to keep its simplicity and related cheapness. We are trying to realize these plans by exchange of laser optical scheme and pumping method $/ 1 \%$

\section{High power $\mathrm{CO}_{2}$ multibeam lasers.}

First of all we have exchange the traditional "consecutive" placement of active elements along single optical axis by "parallel" one. MBI consists of many parallel gas discharge cooled tubes, arranged between two flat resonator mirrors. In result of such exohange of optical. scheme the necessary number of optical elements may be minimized down to two ones. At the same time such optioal scheme gives us the possibility to remove physical reasons of laser power limitation. 
Many construction problems of diffusionally cooled $\mathrm{CO}_{2}$ lasers may be decided successfully in result of exchange DC discharge excitation by $10-20 \mathrm{kHz} A C$ one. It gives us the possibility to use reliable and cheap power supply, to create homogeneous discharge with the same currents in many discharge tubes, to reduce power supply voltage, to increase the pumping efficiency, to minimize the quantity of current collectors and to create quite simple and compact electrodless construction of laser arrays.

The history and main results of multibeam co laser development at our Institute are illustrated in Table. After ${ }^{2}$ successful tests of 1 and $2 \mathrm{~kW}$ experimental devices the industrial $2 \mathrm{~kW}$ multibeam $\mathrm{CO}$ laser was created and now our industry produces some tenses of such lasers for a year. On the fourth line of Table the parameters of last experimental $10 \mathrm{~kW}$ laser are shown. These results demonstrate the principal possibility of creation of multibeam co laser systems consisted of some unify modules. The creation of $50 \div 100^{2} \mathrm{~kW} \mathrm{CO}_{2} \mathrm{MBL}$ is quite possible now. For example, $50 \mathrm{~kW}$ laser may consist of $43 \mathrm{~m}$ length modules. Fach of them consists of " 250 tubes with inner diameter $\sim 1 \mathrm{~cm}$. The total aperture of such array does not exceed $20 \div 25 \mathrm{~cm}$.

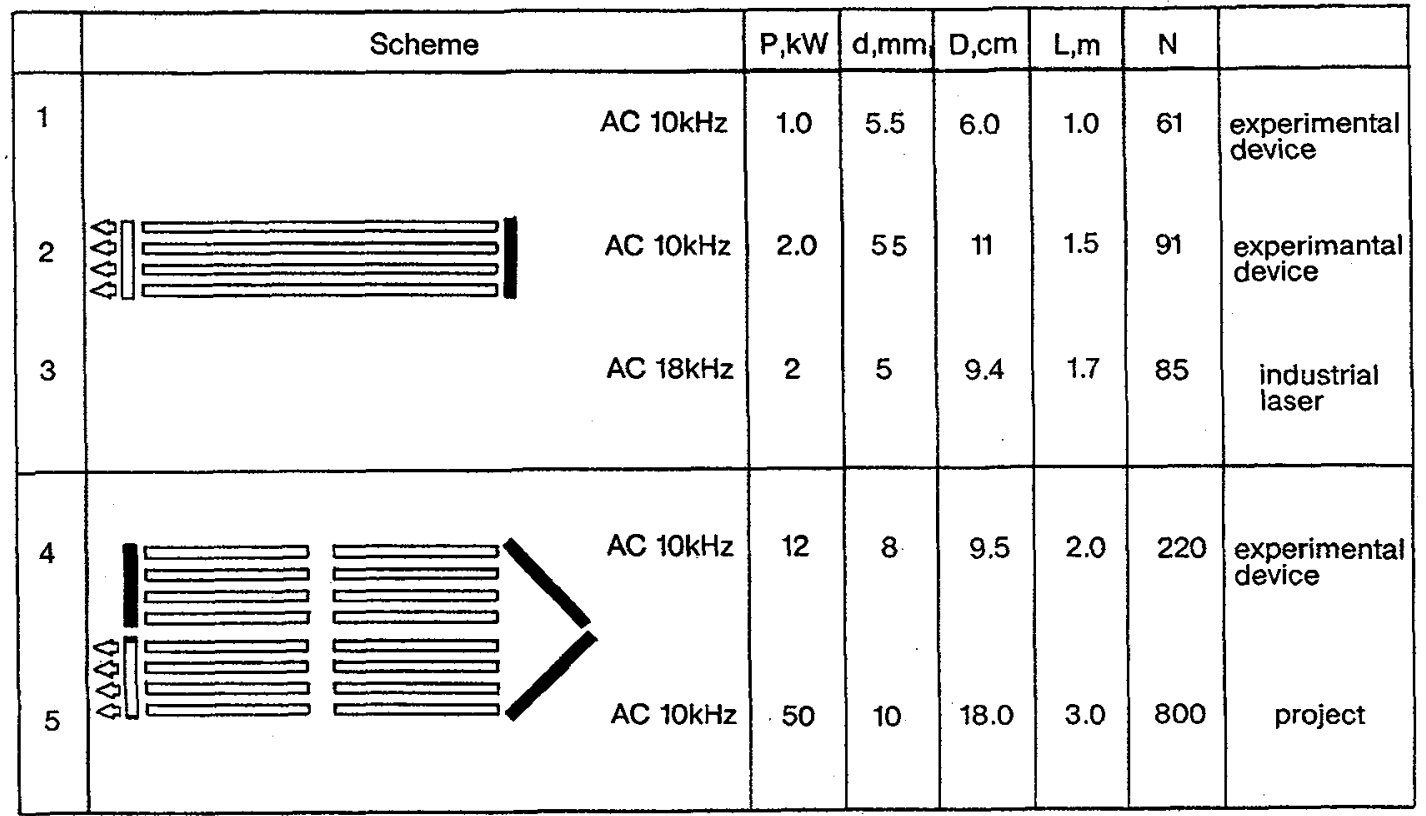

\section{3. $\mathrm{CO}_{2}$ multibeam laser application.}

The sphere of multibeam $\mathrm{CO}_{2}$ laser application for thermal treatment is conditioned by properties of their far-lield intensity distribution. Because of incoherent generation of all lasers in array the sumning of single laser intensity takes place in far-field and, as a result we have smooth, Gauss like distribution in focal plan and slightly modulated one near it. The maximal multibeam laser power density does not exceed the level

$$
I_{i} \ll P_{I} I_{T} N / \pi(\lambda / d)^{2} F_{o p t}^{2}
$$


Its value for lasers, mentioned in Table lies in diapason from $100 \mathrm{~kW}$ to $1 \mathrm{MW} / \mathrm{cm}^{2}$.

Because of high power and intensity distribution and possibility of production of smooth or flat far-field intensity distribution in large spots $\mathrm{CO}_{2}$ MBI are very effective energy sources for different thermal surface ${ }^{2}$ treatment. In USSR $2-3 \mathrm{~kW}$ MBI are used in machine-building for hardening, alloyage and building-up of a big variety of parts, when large areas, homogeneous and large thickness of surface treatment are needed. The more successfully these lasers are used now for hardening of oylinders of diesel locomotive and marine engines, hardening and reconditioning of internal-combustion engine cranks hafts, hardening of guides and rigs in machine-tool constmuction and machine-building, hardening and reconditioning of a number of automobile and agrioultural machinery parts, hardening of punches and press forms and so all.

The productiveness of these prooesses of laser treatment depend on laser power linearly. The price of these lasers increases with power increase less swiftiy. So the economical efficienoy of these laser aplication will increase, when laser power increases. 50 and more power MBL would be widely used in heavy engineering and metaliurgical industries, for example, for hardening of rolling-mill fellings.

\section{Phase locked multibeam $\mathrm{CO}_{2}$ lasers.}

In spite of progress in $\mathrm{CO}_{2}$ MBI development their potential possibilities have not be used completely. The main demerit of these systems is the limited intensity. It may be removed if all lasers in array are phase locked. In this case the addition of electromagnetic wave amplitudes of different lasers takes place in far-field and as a result the intensity in interference picture main lobe with dimension $\lambda / D$ will increase $\mathrm{N}^{2}$ up to the level

$$
I_{c}=I_{i} K(D / d)^{2} \quad I_{i}
$$

where $K$ - is a array filling coefficient. In this case the laser power density may be increased up to $10 \div 100 \mathrm{MW} / \mathrm{cm}^{2}$ for real laser systems. Such power density increase extends the sphere of MBI applioations. For example, phase locked MBI may be used for all type of thermal treatment, including outting and welding. The practice realization of this idea demands decision of some scientific and technical problems. The most important of them are: the phase locking of laser array and the redistribution of laser power from side lobes to the central diffraction maximum.

We have offered and investigated in detail three new different methods of laser array phase locking. In first of them $/ 2 /$ the phase coupling of individual lasers was achieved in result of the diffraction, increasing while one of the resonator mirrors was moving away. In the second case $/ 3 /$ we have used successfully the periodical wave front self-image or so-called Talbot effect. In the last case /4/ we have used spatial filter, in one of the multiplication planes, where radiation spots, corresponding to different supermode are situated in different places. This filter inserts the losses for incoherent radiation and for some of coherent modes ones at the same time and as a result we have the possibility to ensures laser beams phase locking and one supermode seleotion simultaneously. The result of these experiments have demonstrated the possibility of effective phase locking and one supermode selection. 
The problem of main lobe energy maintenance increase is very important one, because of the main lobe of far-field intensity distribution of coherent laser arrays keeps the quite small part of the whole power. In real situation it does not exceed 30-40\%, that is equaled to array transparenoy. Taking into account the high power level of our $\mathrm{CO}_{2}$ lasers, we thing, that the more perspective methods of main lobe power ${ }^{2}$ increase are ones based on aperture filling.

We have suggested and studied in detail two new methods of main lobe power increase, in which both wave and geometrical optio properties of laser beams are used /5/. In first of them the multiplication of uniphase laser beams in one of the Fresnel plane and the following correction of wave front with help of binary phase corrector were used. Our calculations and experimental results shown the possibility of main lobe energy maintenance increase up to $80 \div 90 \%$. In the second methods the aperture filling and corresponding main lobe power maintenance increase is a result of geometrical multiplication of periodic beams with help of speoial amplitude-phase corrector. This oorrector increases the number of output beams twice and can change the phase differenoe between neighbor ones. Our experimental results corroborate the possibility of main lobe power maintenance increase up to 80 - $90 \%$ for real high power $\mathrm{CO}_{2}$ laser arrays.

The different possibilities of phase locking, selection and main lobe power increase, wich have been demonstrated at our experiments, open the real way to development of experimental phase locking systems for real MBI. Now we are developing the system for $2 \mathrm{~kW}$ MBL, consisting of 85 gasdischarge $2 \mathrm{~m}$ tubes with output aperture $85 \mathrm{~mm}$. With help of this system we plan to achieve divergency-10 maintenance - $80 \%$ and common efficiency 50\%. The first testings of phase grid and telesoope resonator have demonstrated the possibility of realization of these plans.

In our opinion presented results may be considered as scientific basis, on which the high power, simple and effective co lasers of next generation may be developed.

\section{References.}

1. Antyukhov V. et all, Kvantovaya Electron. (Moscow), 7 (1980) 425.

2.Glova A. et all, Sov. Tech. Phys. Lett., 11 (1985) 102.

3. Antyukhov $\nabla$. et all, JETP Lett., 44 (1986) 78.

4.Golubenzev A. et ali, Kvantovaya Electron. (Moscow), 17 (1990) 1018.

5. Antyukhov V. et aII, SPIE Vol.1397 8 Int. Sym. on Gas Flow and Chemical Lasers (1990) 355. 